\title{
In vitro correlation between anti-inflammatory and anti-oxidant effects of stone and seed of peaches cultivars
}

\author{
Kyung-Mi Jung $^{1 *}$, Seung-hwa Baek ${ }^{2}$ \\ ${ }^{1}$ Cheongdo Peach Research Institute, GyeongSangBuk-Do Agricultural Technology Administration, Cheongdo 38315, Korea \\ ${ }^{2}$ Department of Predictive Toxicology, Korea Institute of Toxicology, Daejeon 34114, Korea
}

\section{복숭아 품종별 핵과 종자의 항염증 및 항산화 효과간의 상관관계}

\author{
정경미 ${ }^{1 *} \cdot$ 백승화 $^{2}$ \\ ${ }^{1}$ 경상북도 농업기술원 청도복숭아연구소 \\ ${ }^{2}$ 안전성평가연구소 예측독성본부 시스템독성연구센터
}

\begin{abstract}
Peach seeds contain a large amount of phenolic components and exhibit excellent physiological effects in various diseases. We examined the antioxidant effects of stone and seed of three peach cultivars (Miwhang, MH; Kanoiwa hakuto, KH; and Cheonhong, CH) by 1,1-diphenyl-2-picrylhydrazyl (DPPH) assay, ferric reducing activity of plasma (FRAP) assay, and cupric ion reducing antioxidant capacity (CUPRAC) reduction. The results showed that the stone extracts of $\mathrm{CH}$ had higher levels of total phenols and flavonoids than those of the other cultivars do, and the stone extracts of $\mathrm{KH}$ and $\mathrm{CH}$ have the potential to reduce DPPH, FRAP, and CUPRAC activities. In addition, we found that KH, MH, and CH stone extracts decreased nitric oxide generation in RAW 264.7 and BV2 cells. The total phenol and flavonoid contents had no significant correlation with anti-oxidant activities. On the other hand, the anti-inflammatory activity had a low linear correlation with anti-oxidant activities and total phenol and flavonoid contents. The present results suggest that the correlation between antioxidant and anti-inflammatory effects of stone and seed, and the appropriate combination of the stone and seed extracts could be used as an anti-inflammatory treatment and prevention material, respectively.
\end{abstract}

Key words : Prunus persica, stone, seed, anti-oxidant, anti-inflammatory

\section{서 론}

생체 내에서 발생하는 활성산소(reactive oxygen species) 는 생체막의 구성 성분인 불포화지방산을 공격하여 과산화 물을 축적시키며, 이로 인해 생체 기능의 저하나 노화 및 각종 성 인병을 유발시킨다. 이러한 활성산소에 대응하는 항산화 활성은 페놀 함량과 상관관계에 있고, 또한 두개 이상의 수산기 $(-\mathrm{OH})$ 를 가지는 페놀성 물질은 항산화 작용

*Corresponding author. E-mail : kmgod@korea.kr Phone : 82-54-373-5486, Fax : 82-54-373-5487

Received 20 November 2017; Revised 3 January 2018; Accepted 9 February 2018.

Copyright (c) The Korean Society of Food Preservation. All rights reserved.
과 항균 작용도 갖는다고 보고되었다 $(1,2)$. 최근 항산화 활 성 연구에서 살구를 비롯하여 포도, 복숭아 등의 종자가 잎이나 과실에 비해 높은 항산화능을 갖는다고 보고되었으 며 $(3,4)$, 이에 따라 과육을 섭취하고 버려지는 종자 등을 활용할 수 있는 방안을 모색해야 할 필요성이 점차 대두되 고 있다.

복숭아(Prunus persica L. Batsch)는 장미과(Rosaceae), 자 두속(Prunus), 복숭아과속(Amygdalus)에 속하는 온대 낙엽 성 과수로서, 주성분은 수분과 당분이며 유기산, 에스테르, 펙틴 등도 풍부하고 과육은 aspartic acid, serine과 같은 아미 노산을 많이 함유하고 있다(5). 복숭아 관련 항산화 및 항염 증 연구에서는 야생 복숭아 가지의 에틸아세테이트 추출물 이 천연 항산화제인 tocopherol 및 합성 항산화제인 $\mathrm{BHA}$ 보 다 탁월한 항산화 효과를 나타내고, hyaluronidase 저해에 
의한 항염증 효과 시험에서는 항염증 표준품인 ketoprofen 보다는 활성이 낮으나, ibuprofen과 indomethacin보다는 높 은 항염증 효과가 나타난다는 연구가 보고되었다(6). 저장 성 시험에서는 $46^{\circ} \mathrm{C}$ 의 열풍 처리로 전반적인 품질은 우수해 졌으며, 폴리페놀 및 플라보노이드 함량과 이에 따른 항산 화 활성은 대조군과 큰 차이를 보이지 않았고(7), 복숭아 과피와 과육의 에틸아세테이트 추출물은 ascorbic acid에 견줄만한 높은 항산화 활성과 항균 활성을 가진다고 보고되 었다(8). 또한, 예로부터 민간에서 한약재로 많이 사용되었 던 도인에 관한 연구로는 죽상동맥경화 예방, 항혈전기능 등 심혈관계 질환에서 우수한 생리적 효과가 보고되었으며 tyrosinase 저해활성이 강한 안식향산 등에 의한 효소적 갈 변현상 억제, in vivo와 in vitro에서 화학적, 생물학적인 인자 에 의한 DNA의 손상을 감지하는 comet assay를 이용한 평가에서 복숭아 종자 추출물은 방사선에 의한 림프구 DNA손상에 대한 방어효과를 가진다고 보고하였다(9-11).

위의 연구결과에서 보는 바와 같이 대부분 과실의 과육 과 종자에 관련된 연구는 많았지만, 복숭아 핵에 관련된 연구는 거의 없는 실정이다. 또한 복숭아의 품종별 종자 및 핵의 기능성 성분의 탐색에 대한 연구결과가 미비한 상태이므로 본 연구에서는 국내에서 재배되고 있는 복숭아 의 품종별 핵과 종자를 이용하여 항산화 및 항염증 활성에 관한 연구를 실시하고, 이에 따른 상관관계를 파악하여 기 능성 식품 및 생리활성 소재를 개발하는 기초자료로 활용하 고자 한다.

\section{재료 및 방법}

\section{실험 재료}

본 연구에 사용한 복숭아(P. persica L. Batsch)는 2014년 경상북도 농업기술원 청도복숭아연구소의 포장에서 수확 한 품종으로 외관이 양호하고 신선한 것으로 균일하게 선별 하였으며, 미황(Mihwang)은 6월 하순, 가납암백도(Kanoiwa Hakuto)와 천홍(Cheonhong)은 각각 7월 하순에 수확하여 사용하였다. 미황은 청도복숭아연구소에서 육성한 품종으 로 과피에 털이 있는 조생종 황육계통이고, 가납암백도는 털이 있는 유모종 백육계통이며, 천홍은 털이 없는 무모종 황육계통이다. 수확 후 과육을 제거한 핵을 건조하여 종자 와 분리한 후 각각 실험에 사용하였다. 각 품종별 과실 특성 은 Table 1에 나타내었다.

\section{시료 준비}

각 품종별 복숭아의 분리한 핵과 종자를 각각 건조한 후 분쇄하여 polyethylene bag으로 포장하여 $-40^{\circ} \mathrm{C}$ 냉동고에 보관하면서 시료로 사용하였다. 분석 시료는 분쇄된 각 시 료 $5 \mathrm{~g}$ 에 $80 \%$ 에탄올을 $1: 10(\mathrm{w} / \mathrm{v})$ 의 비율로 1 일간 $75^{\circ} \mathrm{C}$,
130 rpm에서 진탕추출한 후(HK-SI25C, Hankuk S\&I Co., Hwaseong, Korea) 여과지(No.2, Whatman ${ }^{\mathrm{TM}}$ International Ltd., Maidstone, UK)로 여과하여 얻은 용액을 감압농축기 (OSB-2000, Eyela Co., Tokyo, Japan)로 농축한 후 DMSO (Sigma-Aldrich Chemical Co., St. Louis, MO, USA)를 용매 로 하여 $10 \mathrm{mg} / \mathrm{mL}$ 및 $20 \mathrm{mg} / \mathrm{mL}$ 의 농도로 설정하여 실험에 사용하였다.

\section{총 phenol 함량 분석}

총 phenol 함량은 Folin-Denis 방법을 변형하여 측정하였 다(12). 96-well plate에 시료액 $(20 \mathrm{mg} / \mathrm{mL}) 2 \mu \mathrm{L}$ 를 증류수 $20 \mu \mathrm{L}$ 와 Folin-Ciocalteu's phenol reagent(Sigma-Aldrich Chemical Co.) $10 \mu \mathrm{L}$ 를 첨가하여 실온에서 6분간 반응시키 고, $7 \% \mathrm{Na}_{2} \mathrm{CO}_{3}$ 용액 $100 \mu \mathrm{L}$ 와 증류수 $70 \mu \mathrm{L}$ 를 첨가하여 실온에서 90 분간 반응시킨 후, $595 \mathrm{~nm}$ 에서 흡광도를 측정 하였다. 표준물질로 gallic acid(Sigma-Aldrich Chemical $\mathrm{Co}$.)를 사용하여 시료와 동일한 방법으로 분석하여 검량선 을 작성한 후 phenol 함량을 산출하였다.

\section{총 flavonoid 함량 분석}

총 flavonoid 함량 측정은 Zhishen 등의 방법을 변형하여 측정하였다(13). 96-well plate에 시료액 $(20 \mathrm{mg} / \mathrm{mL}) 2 \mu \mathrm{L}$ 를 증류수 $100 \mu \mathrm{L}$ 와 $5 \% \mathrm{NaNO}_{2}$ 용액 $5 \mu \mathrm{L}$ 를 혼합하여 실온에 서 10 분간 반응 시키고, $10 \% \mathrm{AlCl}_{3} \cdot 6 \mathrm{H}_{2} \mathrm{O}$ 용액 $10 \mu \mathrm{L}$ 를 첨가하여 다시 실온에서 10 분간 반응시킨 후, $1 \mathrm{M} \mathrm{NaOH}$ (Sigma-Aldrich Chemical Co.) 용액 $40 \mu \mathrm{L}$ 와 증류수 $45 \mu \mathrm{L}$ 를 첨가하여 $405 \mathrm{~nm}$ 에서 흡광도를 측정하였다. 표준물질로 catechin(Sigma-Aldrich Chemical Co.)을 사용하여 시료와 동일한 방법으로 분석하여 검량선을 작성한 후 총 flavonoid 함량을 산출하였다.

\section{1-Diphenyl-2-picrylhydrazyl(DPPH) radical 소거 활성 측정}

$\mathrm{DPPH}$ radical 소거 활성 측정은 Blois의 방법을 변형하여 측정하였다(14). 96-well plate에 시료액 $(20 \mathrm{mg} / \mathrm{mL}) 2 \mu \mathrm{L}$ 와 $50 \%$ 에탄올에 녹인 $40 \mathrm{mM}$ DPPH(Sigma-Aldrich Chemical Co.) 용액 $198 \mu \mathrm{L}$ 를 가하여 총액의 부피가 $200 \mu \mathrm{L}$ 가 되도록 하였다. 이 반응액을 실온에서 빛을 차단하여 약 10 분간 반응시킨 후 분광광도계로 $517 \mathrm{~nm}$ 에서 흡광도를 측정하였 다. 결과는 추출물의 첨가구와 무 첨가구의 흡광도를 통해 백분율로 나타내었다.

DPPH radical scavenging activity $(\%)=[(\mathrm{A}$ control-A sample)/A control] $\times 100$

\section{A : Absorbance at OD $517 \mathrm{~nm}$}


Table 1. Quality characteristics of peach fruit

\begin{tabular}{cccccccc}
\hline Cultivar ${ }^{1)}$ & $\begin{array}{c}\text { Ripening time } \\
(\text { month/day })\end{array}$ & $\begin{array}{c}\text { Weight } \\
(\mathrm{g})\end{array}$ & $\begin{array}{c}\text { Sugar content } \\
\left({ }^{\circ} \mathrm{Bx}\right)\end{array}$ & $\begin{array}{c}\text { Total acidity } \\
(\%)\end{array}$ & $\begin{array}{c}\text { Hardness } \\
(\mathrm{kg} / \varnothing 5 \mathrm{~mm})\end{array}$ & $\begin{array}{c}\text { Hairy } \\
\text { /Hairless }\end{array}$ & Color \\
\hline $\mathrm{MH}$ & $6 / 28$ & 250 & 11.5 & 0.13 & 0.53 & Hairy & Yellow \\
$\mathrm{KH}$ & $7 / 19$ & 251 & 11.8 & 0.12 & 0.92 & Hairy & White \\
$\mathrm{CH}$ & $7 / 20$ & 245 & 10.8 & 0.80 & 1.43 & Hairless & Yellow \\
\hline
\end{tabular}

${ }^{11} \mathrm{MH}$, Miwhang; KH, Kanoiwa Hakuto; CH, Cheonhong.

Ferric ion reducing antioxidant power(FRAP) assay에 의한 환원력 측정

FRAP assay는 Benzie 등의 방법을 변형하여 측정하였다 (15) 실험을 위한 반응액은 $300 \mathrm{mM}$ acetate buffer(pH 3.6), $10 \mathrm{mM}$ 2,4,6-tripyridyl-s-triazine(TPTZ)(Sigma-Aldrich Chemical Co.), $20 \mathrm{mM} \mathrm{FeCl}_{3} \cdot 6 \mathrm{H}_{2} \mathrm{O}$ (Sigma-Aldrich Chemical Co.)을 10:1:1의 부피비로 섞어서 제조하였으며, 실험 직전 에 만들어 사용하였다. 96-well plate에 시료액 $(20 \mathrm{mg} / \mathrm{mL})$ $6 \mu \mathrm{L}$ 와 FRAP 용액 $194 \mu \mathrm{L}$ 를 혼합한 후 실온에서 빛을 차단한 상태로 10 분간 반응시킨 후 $595 \mathrm{~nm}$ 에서 흡광도를 측정하였다. 결과는 무첨가구(DMSO)에 대한 첨가구의 fold 값으로 나타내었다.

Cupric ion reducing antioxidant capacity (CUPRAC) assay에 의한 환원력 측정

CUPRAC assay는 구리 이온의 환원력을 이용하여 radical 을 환원시킬 수 있는 능력을 확인하는 방법으로 Apak 등의 방법을 변형하여 측정하였다(16). $\mathrm{DW}: 10 \mathrm{mM} \mathrm{CuCl}_{2}: 75$ $\mathrm{mM}$ neocuproine(Sigma-Aldrich Chemical Co.)을 100:1:1의 부피비로 혼합하여 실험 직전에 사용하였다. 96-well plate 에 시료액 $(20 \mathrm{mg} / \mathrm{mL}) 6 \mu \mathrm{L}$ 와 CUPRAC 용액 $194 \mu \mathrm{L}$ 를 혼합 한 후 $37^{\circ} \mathrm{C}$ 에서 빛을 차단한 상태로 20 분간 반응시켜 450 $\mathrm{nm}$ 에서 흡광도를 측정하였다. 결과는 FRAP assay와 마찬 가지로 무첨가구(DMSO)에 대한 첨가구의 fold 값으로 나 타내었다

\section{세포 배양}

본 실험에 사용된 RAW 264.7 세포주와 BV2 세포주는 한국세포주은행(Korean Cell Line Bank, Seoul, Korea)에서 분양받아 사용하였다. RAW 264.7 세포주는 $10 \% \mathrm{FBS}$ (Standard fetal bovine serum, HyClone, Logan, UT, USA), penicillin G(Sigma-Aldrich Chemical Co., $100 \mathrm{IU} / \mathrm{mL}$ )와 streptomycin(Sigma-Aldrich Chemical Co., $100 \mu \mathrm{g} / \mathrm{mL}$ )이 첨 가된 $\mathrm{DMEM}$ 배지를 사용하여 $\mathrm{CO}_{2}$ incubator $\left(5 \% \mathrm{CO}_{2}, 95 \%\right.$ air)에서 $37^{\circ} \mathrm{C}$ 의 조건으로 배양하였다. 각 실험에서 세포는 시료를 lipopolysaccharide(LPS, Sigma-Aldrich Chemical Co.) 첨가 1 시간 전에 처리하여 배양한 후, $1 \mu \mathrm{g} / \mathrm{mL}$ 농도의 $\mathrm{LPS}$ 를 처리하여 실험을 진행하였다. 또한 생쥐의 뇌신경소 교세포(mouse microglial cell line)인 BV2 세포도 위의 조건
과 동일한 조건에서 배양하였다.

세포 독성

RAW 264.7 세포에서 복숭아 핵 및 종자 추출물의 세포 독성을 확인하기 위해 3-(4,5-dimethylthiazol-2-yl)-2,5diphenyltetrazolium bromide(MTT) 시험법을 실시하였다. RAW 264.7 세포를 $5 \times 10^{5}$ cells $/ \mathrm{mL}$ 로 96-well plate에 접종하 고, 1 시간 배양 후, 시료를 $100 \mu \mathrm{g} / \mathrm{mL}$ 의 농도로 처리하여 1 시간 동안 배양하였다. 시료가 처리된 세포에 LPS를 1 $\mu \mathrm{g} / \mathrm{mL}$ 의 농도로 처리한 다음 $37^{\circ} \mathrm{C}$ 에서 22 시간 배양시켰다. 배지에 희석된 MTT(Sigma-Aldrich Chemical Co.) 용액(0.5 $\mathrm{mg} / \mathrm{mL}$ )을 세포에 처리하여 4시간 후 MTT를 환원시켜 생 성된 formazan이 배지에서 분리되지 않도록 배지를 제거하 였다. 생성된 MTT-formazan은 DMSO에 용해시켜 $540 \mathrm{~nm}$ 에서 흡광도를 측정하였다.

Nitric oxide(NO) 라디칼 소거활성 측정

RAW 264.7 세포에 농도별 시료를 처리 한 후 LPS를 $1 \mu \mathrm{g} / \mathrm{mL}$ 의 농도로 처리하여 24시간 배양하였다. 배양 후 배양액에 생성된 NO의 양은 griess reagent( $1 \%$ sulfanilic acid:1\% napthylamine=1:1)를 이용하여 $490 \mathrm{~nm}$ 에서 흡광도 를 측정하였다.

\section{통계처리}

통계처리는 각 그룹 간의 차이를 보기위해 SAS프로그램 을 이용하여 분산분석(analysis of variance)을 실시하고 유 의수준 $\mathrm{p}<0.05$ 에서 유의적인 차이를 보인 경우 Duncan의 다중범위 시험법(Duncan' multiple arange test)을 적용하여 사후분석을 실시하였다.

\section{결과 및 고찰}

총 phenol 함량 및 총 flavonoid 함량

품종별 복숭아 핵과 종자를 에탄올로 추출하고 총 phenol 함량과 총 flavonoid 함량을 측정한 결과는 Table 2 와 같다. Polyphenol 화합물은 분자 하나에 phenol 그룹이 한 개 이상 있는 것으로 식물에서 널리 발견된다(17). Polyphenol의 많 은 수산기는 반응성이 높은 활성 산소 제거에 쓰이며, 여러 
단백질 내에 존재하는 sulfhydryl(-SH) 그룹 및 다른 단백질 부분과 결합하는 성질이 있기 때문에 병원균에 대한 항균 작용, 신체대사에 작용 하는 효소 활성 변화 촉진, 유전자 발현 촉진 등의 작용을 한다. 또한 활성 산소 제거 및 노화 억제 등의 항산화 기능을 가지고 있어 각종 질환 치료 및 예방에 이용되고 있다(18). 미황, 가납암백도 및 천홍 핵의 총 phenol 함량은 각각 $89.78 \pm 1.51,207.16 \pm 2.40$ 및 $218.50 \pm 7.21 \mathrm{mg} \mathrm{GAE} / \mathrm{g}$ 으로 나타나 미황 핵의 phenol 함량 에 비해 가납암백도 핵은 2.3 배, 천홍 핵은 2.4 배 더 높은 함량을 보였다 $(\mathrm{p}<0.05)$. 반면, 미황, 가납암백도 및 천홍 종자의 총 phenol 함량은 각각 $20.39 \pm 0.08,33.00 \pm 0.33$ 및 $24.15 \pm 0.14 \mathrm{mg} \mathrm{GAE} / \mathrm{g}$ 으로 나타나 가납암백도 종자의 총 phenol 함량이 가장 높은 것으로 나타났다.

Flavonoid는 flavone을 기본 구조로 갖는 식물의 황색 계 통의 색소의 총칭으로 phenol류도 그 안에 포함된다(19). Flavonoid는 유해산소 및 지질 산화를 방지하는 항산화능 뿐만 아니라 항균, 항암, 항염증, 항동맥경화 등의 효과가 있는 것으로 알려져 있다(20). 미황, 가납암백도및 천홍 핵 의 flavonoid 함량은 각각 $28.11 \pm 0.11,110.36 \pm 2.16$ 및 $172.22 \pm 2.62 \mathrm{mg} \mathrm{CE} / \mathrm{g}$ 으로 나타나 미황 핵의 flavonoid 함량 에 비해 가납암백도 핵은 3.9 배, 천홍 핵은 6.1 배 더 높은 함량을 보였다( $\mathrm{p}<0.05)$. 반면 종자의 flavonoid 함량은 미황, 가납암백도 및 천홍에서 각각 $10.59 \pm 0.49,5.88 \pm 0.06$ 및 $6.77 \pm 0.11 \mathrm{mg} \mathrm{CE} / \mathrm{g}$ 이었으며 미황 종자의 flavonoid 함량이 가장 높았는데, 이는 가납암백도와 천홍과 유의적인 차이 를 보였다.

Table 2. Total phenol and flavonoid contents in stone and seed of peaches

\begin{tabular}{ccccc}
\hline \multirow{2}{*}{ Cultivar $\left.^{1}\right)^{1}$} & \multicolumn{2}{c}{$\begin{array}{c}\text { Total phenol content } \\
(\mathrm{mg} \mathrm{GAE} / \mathrm{g})^{2)}\end{array}$} & \multicolumn{2}{c}{$\begin{array}{c}\text { Total flavonoid content } \\
(\mathrm{mg} \mathrm{CE} / \mathrm{g})^{3)}\end{array}$} \\
\cline { 2 - 5 } & Stone & Seed & Stone & \multicolumn{1}{c}{ Seed } \\
\hline MH & $89.78 \pm 1.51^{4) 65)}$ & $20.39 \pm 0.08^{\mathrm{c}}$ & $28.11 \pm 0.11^{\mathrm{c}}$ & $10.59 \pm 0.49^{\mathrm{a}}$ \\
$\mathrm{KH}$ & $207.16 \pm 2.40^{\mathrm{a}}$ & $33.00 \pm 0.33^{\mathrm{a}}$ & $110.36 \pm 2.16^{\mathrm{b}}$ & $5.88 \pm 0.06^{\mathrm{b}}$ \\
$\mathrm{CH}$ & $218.50 \pm 7.21^{\mathrm{a}}$ & $24.15 \pm 0.14^{\mathrm{b}}$ & $172.22 \pm 2.62^{\mathrm{a}}$ & $6.77 \pm 0.11^{\mathrm{b}}$ \\
\hline
\end{tabular}

${ }^{1)} \mathrm{MH}$, Miwhang; KH, Kanoiwa Hakuto; CH, Cheonhong.

${ }^{2)}$ Expressed as $\mathrm{mg}$ gallic acid equivalent.

${ }^{3}$ Expressed as mg catechin equivalent.

${ }^{4} \mathrm{Mean} \pm \mathrm{SD}(\mathrm{n}=3)$.

${ }^{5}$ Different letters in the same column indicate significantly different at $\mathrm{p}<0.05$.

\section{항산화 활성}

복숭아 품종별 핵과 종자 추출물의 항산화 활성 결과는 Table 3과 같다. 비교적 안정한 radical인 1,1-diphenyl-2picrylhydrazyl(DPPH)은 항산화 활성을 갖는 물질과 만나면 환원되어 색이 탈색되는 점을 이용한 항산화 활성 측정 방법으로 $\mathrm{DPPH}$ 의 환원 정도를 기준으로 측정물질의 환원 력과 항산화력을 확인하는 방법으로 알려져 있다(21). 복숭 아 품종별 핵과 종자의 DPPH 항산화 활성을 비교한 결과,
천홍 핵이 $74.2 \pm 1.0 \%$ 로 가장 높은 radical 소거능을 나타냈 으며, 가납암백도와 미황이 각각 $73.3 \pm 3.6 \%, 32.8 \pm 1.4 \%$ 의 소거능을 나타냈다. 또한, 종자에서는 천홍이 $19.7 \pm 0.3 \%$ 의 소거능을 나타냈으며 미황과 가납암백도가 각각 $17.2 \pm$ $0.9 \%, 13.9 \pm 0.9 \%$ 로 나타내었다(Tabel 3). 이는 핵 추출물에 서 천홍과 가납암백도의 높은 phenol과 flavonoid 함량에 기인하는 것으로 판단되며, 총 phenol 및 flavonoid 함량의 증가에 따른 높은 항산화 활성 증가에 대한 연구 결과와 일치하였다(22).

FRAP에 의한 항산화 활성은 free radicals 없이 electron transfer에 기초한 방법으로 시료 추출물 처리 후 ferric tripyridyltriazine $\left(\mathrm{Fe}^{3+}-\mathrm{TPTZ}\right)$ 을 ferrous tripyridyltriazine $\left(\mathrm{Fe}^{2+}-\right.$ TPTZ)으로 환원시키는 능력을 측정 하는 방법이다(23). 3 품종의 핵과 종자의 FRAP value를 확인한 결과, 무첨가구 에 비해 핵 추출물에서 각각 천홍, 가납암백도, 미황이 26.8 배, 23.8배, 12.4 배의 순으로 높은 활성을 나타내었고, 천홍 이 유의적으로 가장 높은 활성을 나타내었다. 반면 종자의 FRAP 수치는 천홍과 가납압백도가 무첨가구에 비해 4.9 배 의 활성을 나타내었고 미황 종자는 3.4 배의 활성을 나타내 었다.

CUPRAC활성은 구리이온 $\left(\mathrm{Cu}^{2+}\right)$ 의 전자를 받아들어 $\mathrm{Cu}^{+}$ 로 환원되는 것을 이용한 방법으로 추출 시료의 $\mathrm{Cu}^{2+}$ 의 환원되는 능력을 통해 항산화 능력을 확인하는 방법이다 (24). 품종별 복숭아 핵과 종자 추출물에서는 무첨가구 대비 가납암백도 핵이 10.3 배의 활성을 나타났으며, 천홍과 미황 이 각각 8.8 배와 8.1 배의 활성이 관찰되었다. 종자 추출물에 서의 CUPRAC 활성은 무첨가구에 비해 천홍, 가납암백도, 미황 순으로 각각 4.9 배, 4.5 배 그리고 3.8 배의 활성을 나타 내었다.

\section{항염증 활성}

본 연구에서는 복숭아 3품종의 핵과 종자 추출물의 항염 증 활성을 조사하기 위해 LPS 자극에 의해 유도된 RAW 264.7 대식세포(macrophage)와 BV2 소교세포(microglia)의 염증 반응에서 nitric oxide(NO)의 억제 활성을 측정하였다. 면역세포중의 하나인 대식세포는 내재면역뿐만 아니라 적 응면역 등 다양한 숙주 반응에 관여하여 많은 항염 작용 연구에 이용되고 있다(25). BV2 소교세포(microglia)는 뇌 에 존재하는 대식세포로 monocyte에서 분화되어 중추신경 계에 있는 비신경세포로 병원균 감염이나 뇌 손상에 대해 반응해 염증성 cytokine, 단백질 분해 효소, 활성 산소 등을 생성하여 보호하는 면역세포이나, 만성 염증이 유발하면 뇌 조직의 손상 및 세포사가 유발되기 때문에 신경 퇴행성 질환의 주요 원인이 되는 것으로 알려져 있다 $(26,27)$.

품종별 복숭아 핵과 종자의 항염증 활성을 측정한 결과 는 Fig. 1, 2와 같다. RAW 264.7 세포에서 각각의 핵 추출물 을 $100 \mu \mathrm{g} / \mathrm{mL}$ 의 농도로 처리한 실험구에서의 $\mathrm{NO}$ 생성량은 
Table 3. Antioxidant capacity in stone and seed of peaches using DPPH, FRAP, and CUPRAC assays

\begin{tabular}{|c|c|c|c|c|c|c|}
\hline \multirow{2}{*}{ Cultivar $^{1)}$} & \multicolumn{2}{|c|}{$\begin{array}{c}\mathrm{DPPH}^{2)} \\
\text { radical scavenging activity }(\%)\end{array}$} & \multicolumn{2}{|c|}{$\begin{array}{c}\text { FRAP }^{3)} \\
\text { Fold (of control) }\end{array}$} & \multicolumn{2}{|c|}{$\begin{array}{c}\text { CUPRAC }^{4)} \\
\text { Fold (of control) }\end{array}$} \\
\hline & Stone & Seed & Stone & Seed & Stone & Seed \\
\hline MH & $32.8 \pm 1.4^{5 \mathrm{bb} 6)}$ & $17.2 \pm 0.9^{b}$ & $12.4 \pm 0.3^{b}$ & $3.4 \pm 0.2^{\mathrm{a}}$ & $8.1 \pm 0.1^{b}$ & $3.8 \pm 0.1^{b}$ \\
\hline $\mathrm{KH}$ & $73.3 \pm 3.6^{\mathrm{a}}$ & $13.9 \pm 0.9^{c}$ & $23.2 \pm 0.2^{\mathrm{ab}}$ & $4.9 \pm 0.0^{\mathrm{a}}$ & $10.3 \pm 0.3^{\mathrm{a}}$ & $4.5 \pm 0.0^{\mathrm{ab}}$ \\
\hline $\mathrm{CH}$ & $74.2 \pm 1.0^{\mathrm{a}}$ & $19.7 \pm 0.3^{a}$ & $26.8 \pm 1.5^{\mathrm{a}}$ & $4.9 \pm 0.1^{\mathrm{a}}$ & $8.8 \pm 0.2^{b}$ & $4.9 \pm 0.0^{\mathrm{a}}$ \\
\hline
\end{tabular}

${ }^{1}$ MH, Miwhang; KH, Kanoiwa Hakuto; CH, Cheonhong.

${ }^{2}$ 1,1-Diphenyl-2-picrylhydrazyl.

${ }^{3)}$ Ferric ion reducing antioxidant power.

${ }^{4)}$ Cupric ion reducing antioxidant capacity.

${ }^{5}$ Mean \pm SD $(n=3)$

${ }^{6}$ Different letters in the same column indicate significantly different at $\mathrm{p}<0.05$.

(A)

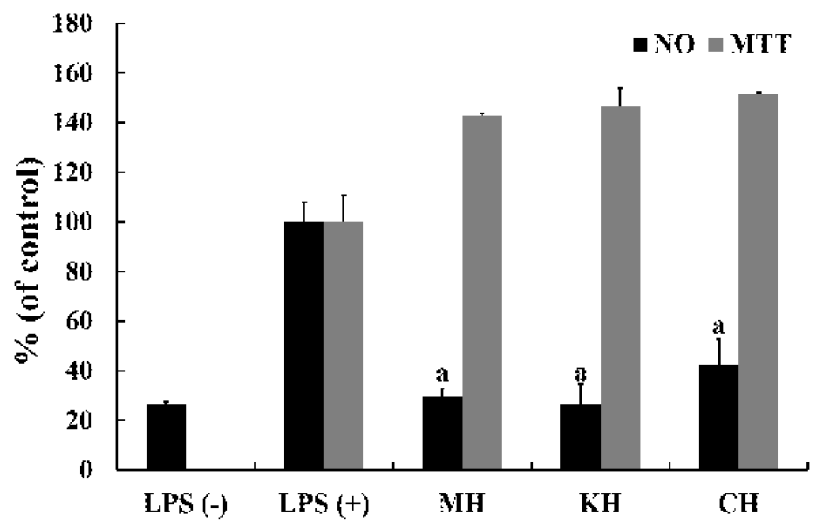

(B)

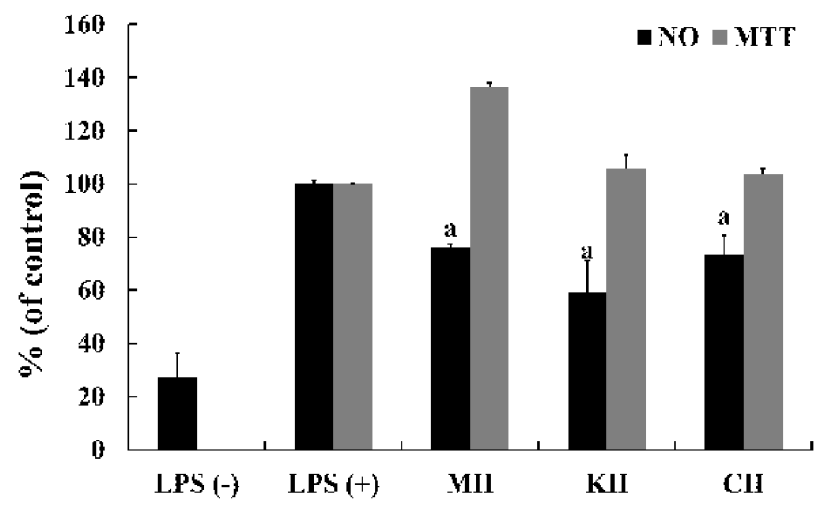

Fig. 1. Effect of (A) stone and (B) seed of peaches on production of nitric oxide and cell viability in RAW 264.7 cells.

MH, Mihwang; KH, Kanoiwa Hakuto; CH, Cheonhong.

Values are means $\pm \mathrm{SD}$ of triplicate determinations. Different superscripts within a column indicate significant differences $(\mathrm{p}<0.05)$. Final concentration, $100 \mathrm{\mu g} / \mathrm{mL}$.

미황이 대조구에 비해 $29.60 \pm 3.09 \%$ 로 관찰되었고, 가납암 백도는 $26.49 \pm 8.02 \%$, 천홍은 $42.10 \pm 10.72 \%$ 로 관찰되었으 며, 품종간의 항염 활성 비교에서 3품종 모두 유의적인 차이
를 나타내지 않았다(Fig 1A). 종자 추출물을 $100 \mu \mathrm{g} / \mathrm{mL}$ 의 농도로 처리한 실험구에서는 각각 미황이 $76.08 \pm 1.40 \%$, 가납암백도가 $59.16 \pm 11.92 \%$ 그리고 천홍이 $73.61 \pm 7.24 \%$

(A)

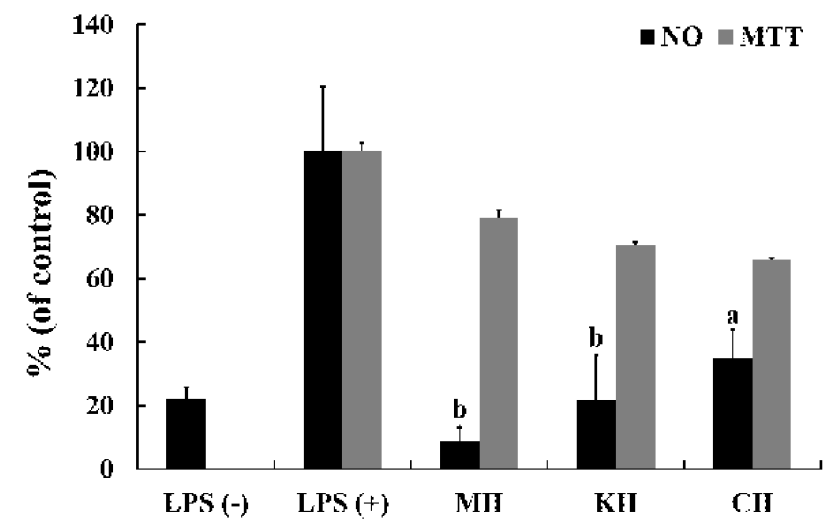

(B)

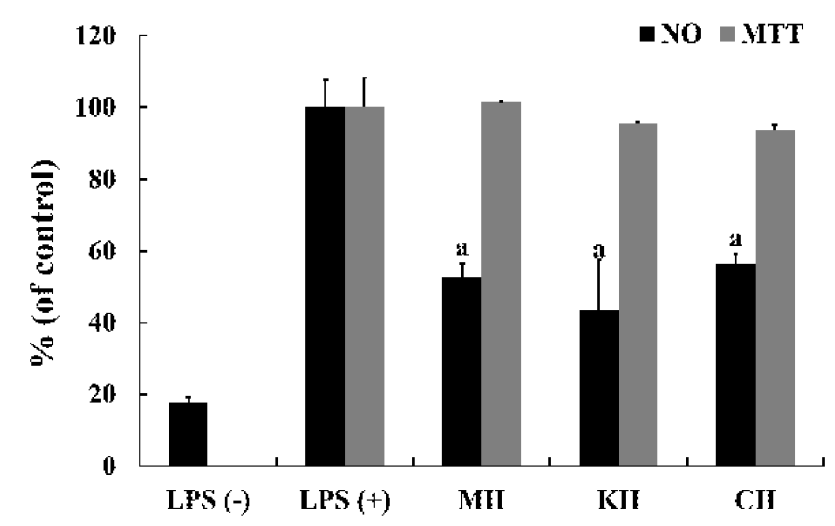

Fig. 2. Effect of (A) stone and (B) seed of peaches on production of nitric oxide and cell viability in BV2 cells.

MH, Mihwang; KH, Kanoiwa Hakuto; CH, Cheonhong.

Values are means $\pm \mathrm{SD}$ of triplicate determinations. Different superscripts within a column $(a-b)$ indicate significant differences $(p<0.05)$. Final concentration, $100 \mu \mathrm{g} / \mathrm{mL}$. 
Table 4. Pearson's correlation coefficients of DPPH, CUPRAC, FRAP, nitric oxide generation in BV2 and RAW 264.7 cells, TPC and TFC

\begin{tabular}{|c|c|c|c|c|c|c|c|}
\hline & $\mathrm{DPPH}^{1)}$ & (UPRAC ${ }^{2)}$ & FRAP $^{3)}$ & $\mathrm{NO}$ in $\mathrm{BV}^{4)}$ & NO in RAW 264.7) & $\mathrm{TPC}^{6}$ & $\mathrm{TFC}^{7}$ \\
\hline DPPH & 1 & $0.900^{* * 8)}$ & $0.970^{* *}$ & -0.049 & $-0.713^{* *}$ & -0.300 & -0.292 \\
\hline CUPRAC & - & 1 & $0.853^{* *}$ & -0.277 & $-0.738^{* *}$ & -0.308 & -0.243 \\
\hline FRAP & - & - & 1 & -0.210 & $-0.761^{* *}$ & -0.253 & -0.288 \\
\hline $\mathrm{NO}$ in BV2 & - & - & - & 1 & 0.482 & -0.112 & -0.036 \\
\hline NO in RAW 264.7 & - & - & - & - & 1 & 0.101 & 0.148 \\
\hline TPC & - & - & - & - & - & 1 & 0.941 \\
\hline TFC & - & - & - & - & - & - & 1 \\
\hline
\end{tabular}

1)1-Diphenyl-2-picrylhydrazyl.

${ }^{2)}$ Cupric ion reducing antioxidant capacity.

${ }^{3)}$ Ferric ion reducing antioxidant power.

${ }^{4)}$ Nitric oxide in BV2 cells.

${ }^{5)}$ Nitric oxide in RAW 264.7 cells.

6) Total phenol content.

7) Total flavonoid content.

${ }^{8}{ }^{*} \mathrm{p}<0.05, \mathrm{p}<0.01$.

로 3품종 모두 유의적인 차이를 나타내지 않았으며, 핵 추출 물에 비해 낮은 항염 활성이 관찰되었다(Fig 1B). 또한, BV2 세포에서 3품종의 핵 추출물의 NO 생성량은 대조구에 비해 각각 미황은 $9.05 \pm 4.02 \%$, 가남압백도는 $21.68 \pm 14.33 \%$ 그 리고 천홍은 $35.03 \pm 8.95 \%$ 로 관찰되었다(Fig $2 \mathrm{~A})$. 특히 미황 과 가납암백도 핵 추출물의 경우 LPS를 처리하지 않은 무처 리구의 NO 생성량과 대비하여 적은양의 $\mathrm{NO}$ 가 관찰되어 강력한 항염 활성을 나타내었으며, 천홍 핵 추출물에 비하 여 7.98-38.95\% 높은 항염 활성을 나타내었다. 또한, 종자 추출물을 처리한 실험구에서는 미황이 $52.63 \pm 3.89 \%$, 가납 암백도는 $43.56 \pm 13.97 \%$, 천홍은 $56.45 \pm 2.73 \%$ 의 NO 생성 량을 나타내었으며, 품종간의 항염 활성 비교에서 3 품종 모두 유의적인 차이를 나타내지 않았다(Fig 2B). 본 연구의 결과로 복숭아 3품종의 핵 추출물은 RAW 264.7 세포 및 $\mathrm{BV} 2$ 세포에서 강력한 항염 활성을 나타내는 것으로 관찰 되었으며, 종자 추출물에서도 대조구에 비해 비교적 높은 항염 활성을 나타내었다. 이와 같은 연구결과는 복숭아 3 품 종의 핵과 종자가 전반적으로 염증 반응의 억제 뿐 만 아니 라 뇌질환 관련 염증 치료 소재 개발의 기초자료로 충분한 가치가 있다고 판단된다.

\section{상관 관계}

복숭아 3품종 핵과 종자의 총 phenol 및 총 flavonoid 함량 의 상관성이 0.941 로 유의적인 높은 상관관계를 나타냈다 $(\mathrm{p}<0.01)$. 항산화 활성간의 상관성은 FRAP 활성과 $\mathrm{DPPH}$ 활성 간의 상관성 $(0.970, \mathrm{p}<0.01), \mathrm{CUPRAC}$ 활성과 $\mathrm{DPPH}$ 라디칼 소거능 간의 상관성 $(0.900, \mathrm{p}<0.01)$ 그리고, CUPRAC 활성과 FRAP 활성의 상관성 $(0.853, \mathrm{p}<0.01)$ 순으 로 모두 유의적으로 정(+)의 관계가 확인되었다. 이에 반해 총 phenol 및 총 flavonoid 함량은 항산화 활성들 간의 상관
관계에서 유의적인 상관성을 나타내지 않았다. 이는 핵과 종자의 항산화 활성이 flavonoid성 phenol 화합물이 아닌 non-flavonoid성 phenol 화합물의 작용에 의한 것으로 예상 되었다. 또한 항염 활성과 항산화 활성들 간의 상관성은 낮게 확인되었으며 항염 활성과 총 phenol 및 flavonoid 함량 간은 낮은 상관관계를 나타내며 이는 flavonoid성 phenol 화합물이 항염 반응에는 낮게 관여한다는 것을 확인 할 수 있다. 따라서 본 연구에서 복숭아 3 품종 핵과 종자의 non-flavonoid성 phenol 화합물이 다양한 항산화 활성뿐 만 아니라 항염 세포 활성에 작용 할 것이라 사료된다.

\section{요 약}

본 연구에서는 현재 재배되고 있는 복숭아 품종 중 미황, 가납암백도 및 천홍의 핵과 종자를 이용하여 항산화 및 항염증 활성에 관한 연구를 하였다. 총 phenol 및 flavonoid 함량은 3품종 모두 종자에 비해 핵에서 월등히 높았으며, 품종간에는 천홍의 핵에서 가장 높은 함량을 나타내었다. DPPH radical 소거능과 FRAP 및 CUPRAC에 의한 항산화 활성은 3품종 모두 종자에 비해 핵에서 활성이 높았고, $\mathrm{DPPH}$ radical 소거활성은 가납암백도와 천홍, FRAP 활성 은 천홍, CUPRAC 활성은 가납암백도에서 유의성 있게 높았다. NO 생성 억제 효과는 RAW 264.7 세포의 경우 핵 추출물에서 가납암백도 $74 \%$, 미황 $70 \%$, 천홍 $58 \%$ 이며. $\mathrm{BV} 2$ 세포의 경우 미황 $90 \%$, 가납암백도 $78 \%$, 천홍 $65 \%$ 로 각각 염증 반응을 감소시켰다. 복숭아 3 품종 핵과 종자의 총 phenol 함량과 총 flavonoid 함량은 높은 상관 관계를 나타내었고, 항산화 활성간의 상관성은 모두 유의적인 관 계가 확인되었으나, 항염 활성과 항산화 활성, 항염 활성과 
총 phenol 및 flavonoid 함량간은 낮은 상관관계를 나타내 었다.

\section{감사의 글}

본 연구는 경상북도농업기술원 연구기술개발지원 사업 의 연구비 지원에 의해 수행되었으며 이에 감사드립니다.

\section{References}

1. Ji EJ, Yoo KM, Park JB, Hwang IK (2008) Preparation of citron peel tea containing yuza (Citrus junos Seib ex TANAKA) and its antioxidant characteristics. Korean J Food Cookery Sci, 24, 460-465

2. Ho CT, Chen Q, Shi H, Zhang KQ, Rosen RT (1992) Antioxidative effect of polyphenol extract prepared from various Chinese teas. Prev Med, 21, 520-525

3. Yoo SJ, Kim SH, Jun MS, Oh HT, Choi HJ, Ham SS (2007) Antioxidative, antimutagenic and cytotoxic effects of Prunus armeniaca extracts. Korean J Food Preserv, 14, 220-225

4. Hwang IW, Lee HR, Kim SK, Zheng HZ, Choi JU, Lee SH, Lee SH, Chung SK (2008) Proanthocyanidin content and antioxidant characteristics of grape seeds. Korean J Food Preserv, 15, 859-863

5. Lee DS, Woo SK, Yang CB (1972) Studies on the chemical composition of major fruits in Korea:On non-volatile organic acid and sugar contents of apricot (maesi), peach, grape, apple and pear and its seasonal variation. Korean J Food Sci Technol, 4, 134-139

6. Cha BC, Lee EH (2004) Antioxidant and antiinflammation activities of Prunus persica tree extracts. Korean J Med crop Sci, 12, 289-294

7. Lee KH, Jang HJ, Lee YJ, Choi JH (2014) Changes in the chemical components and antioxidant activity of peach (Prunus persica L. Batsch) by hot air treatment. Korean J Food Nutr, 27, 219-224

8. Park KK (2008) Studies on functions of Prunus persica to develop as the functional food. Report of Rural Development Administration RDA SE0000106586, Suwon, Korea, p 18-26

9. Yun IH, Seo BI, Kim SH (1996) The effect of Persicae Semen on the artherosclerosis in rabbit. Korean J Herbol, 11, 79-79

10. Lee JY, Hong SG, Choi SW (2000) Inhibition of enzymatic browning of apple juices by benzoic acid isolated from peach (Prunus persica Batsch) seeds. Korean J Postharvest Sci Technol, 7, 103-107

11. Kim JK, Lee CJ, Park TW, Chai YG (1999) Protective effect of peach kernel extracts on radiation-induced DNA damage in human blood lymphocytes in the comet assay. Paper presented at 1999 spring meeting of the Korean Nuclear Society, May 28-29, Taejon, Korea

12. Folin O, Denis W (1912) On phosphotungsticphosphomolybdic compounds as color reagents. J Biol Chem, 12, 239-243

13. Zhishen J, Mengcheng T, Jianming W (1999) The determination of flavonoid contents in mulberry and their scavenging effects on superoxide radicals. Food Chem, 64, 555-559

14. Blois MS (1958) Antioxidant determinations by the use of a stable free radical. Nature, 181, 1199-1200

15. Benzie IF, Strain JJ (1996) The ferric reducing ability of plasma (FRAP) as a measure of "antioxidant power": the FRAP assay. Anal Biochem, 239, 70-76

16. Apak R, Guclu K, Ozyurek M, Karademir SE (2004) Novel total antioxidant capacity index for dietary polyphenols and vitamins $\mathrm{C}$ and $\mathrm{E}$, using their cupric ion reducing capability in the presence of neocuproine: CUPRAC method. J Agric Food Chem, 52, 7970-7981

17. Hammerstone JF, Lazarus SA, Schmitz HH (2000) Procyanidin content and variation in some commonly consumed foods. J Nutr, 130, 2086-2092

18. Kim YJ (2009) Evaluation of Antioxidant activity and thermal stability of plant polyphenols. Biomater Res, 13, 30-36

19. Bonina F, Lanza M, Montenegro L, Puglisi C, Tomaino A, Trombetta D, Castelli F, Saija A (1996) Flavonoids as potential protective agents against photo-oxidative skin damage. Int J Pharm, 145, 87-94

20. Di Carlo G, Mascolo N, Izzo AA, Capasso F (1999) Flavonoids: old and new aspects of a class of natural therapeutic drugs. Life Sci, 65, 337-353

21. Chrzczanowicz J, Gawron A, Zwolinska A, de Graft-Johnson J, Krajewski W, Krol M, Markowski J, Kostka T, Nowak D (2008) Simple method for determining human serum 2,2-diphenyl-1-picryl-hydrazyl (DPPH) radical scavenging activity-possible application in clinical studies on dietary antioxidants. Clinic Chem Lab Med, 46, 342-349

22. Chen S, Shen X, Cheng S, Li P, Du J, Chang Y, Meng H (2013) Evaluation of garlic cultivars for polyphenolic 
content and antioxidant properties. PLoS One, 8, e79730

23. Yoo KM, Kim DO Lee CY (2007) Evaluation of different methods of antioxidant measurement. Food Sci Biotechnol, $16,177-182$

24. Ozyurek M, Bektasoglu B, Guclu K, Apak R (2008) Hydroxyl radical scavenging assay of phenolics and flavonoids with a modified cupric reducing antioxidant capacity (CUPRAC) method using catalase for hydrogen peroxide degradation. Anal Chim Acta, 616, 196-206

25. Kim TY (2013) Effect of Gagam-Danguieumja through regulation of MAPK on LPS-induced inflammation in RAW 264.7 cells. Korean J Orient Internal Med, 34, 339-348

26. Kreutzberg GW (1996) Microglia: a sensor for pathological events in the CNS. Trends neurosci, 19, 312-318

27. Cheong MH, Lee SR, Yoo HS, Jeong JW, Kim GY, Kim WJ, Jung IC, Choi YH (2011) Anti-inflammatory effects of Polygala tenuifolia root through inhibition of $\mathrm{NF}-\kappa \mathrm{B}$ activation in lipopolysaccharide-induced BV2 microglial cells. J Ethnopharmacol, 137, 1402-1408 